ISSN 0258-7122 (Print), 2408-8293 (Online)

Bangladesh J. Agril. Res. 41(1): 91-101, March 2016

\title{
RESPONSE OF N, P AND K ON THE GROWTH AND FLOWERING OF HIPPEASTRUM (Hippeastrum hybridum Hort.)
}

\author{
M. K. JAMIL ${ }^{1}$, M. MIZANUR RAHMAN ${ }^{2}$, M. MOFAZZAL HOSSAIN ${ }^{3}$ \\ M. TOFAZZAL HOSSAIN ${ }^{4}$ AND A. J. M. SIRAJUL KARIM ${ }^{5}$
}

\begin{abstract}
An experiment was conducted at the Horticultural Research Field of Bangabandhu Sheikh Mujibur Rahman Agricultural University (BSMRAU), Salna, Gazipur during September 2008 to May 2009 to determine the response of hippeastrum (cu. 'Apple Blassom) to different combinations of nitrogen, phosphorus and potassium levels. There were 14 treatment combinations comprising four levels of nitrogen viz. 0, 100, 200, and $300 \mathrm{kgha}^{-1}$; five levels of phosphorus viz. 0, 200,300, 400 and $500 \mathrm{kgha}^{-1}$ and five levels of potassium viz. 0, 100, 200, 300 and $400 \mathrm{kgha}^{-1}$ with an exclusively Cowdung treatment at the rate of 10 tha $^{-1}$. The experiment was laid out in a Randomized Complete Block Design with three replications. The growth and flowering parameter of hippeastrum were significantly influenced by combined application of N, P \& $\mathrm{K}$.The highest values in respect of leaves per plant $(8.6)$, leaf breadth $(5.4 \mathrm{~cm})$, number of plants per bulb (3.07), flower scape per plant (2.07), flowers per scape (4.2), length and diameter of flower $(14 \mathrm{~cm} \mathrm{x} 13.83 \mathrm{~cm})$, flower scape $(43.33 \mathrm{~cm}$ $x 29.37 \mathrm{~cm}$ ) and flowering duration (10.7 days) were observed with $\mathrm{N}_{200} \mathrm{P}_{400} \mathrm{~K}_{300}$. The same treatment showed earliness in days to flower scape emergence (172.3 days), days to flower bud appearance (185.3 days) and days to first flower open (189.3 days). The biggest flower $(14.00 \mathrm{~cm} \times 13.83 \mathrm{~cm})$, longest flower scape $(43.33 \mathrm{~cm})$, maximum number of flowers per scape (4.20), and maximum flowering duration (11.5 days) were also exhibited by the treatment $\mathrm{N}_{200} \mathrm{P}_{400} \mathrm{~K}_{300}$ The control treatment $\left(\mathrm{N}_{0} \mathrm{P}_{0} \mathrm{~K}_{0}\right)$ recorded the lowest values except days to first leaf emergence, days to flower scape emergence, days to flower bud appearance and days to first flower open.
\end{abstract}

Keywords: Hippeastrum, Nitrogen, Phosphorus, Potassium, flower yield.

\section{Introduction}

Hippeastrum (Hippeastrum hybridum Hort.) is a newly introduced flower in Bangladesh. It is an ornamental bulbous flowering plant belonging to the family Amaryllidaceae having large and showy flowers with many bright colours (Zandbergen, 1980) which is commonly known as Royal Dutch Amaryllis (Jana, 1995). They are suitable for planting in the bed, pot, rockery, shrubbery, greenhouse

${ }^{1}$ Senior Scientific Officer, Biotechnology Division, Bangladesh Agricultural Research Institute (BARI), Gazipur, ${ }^{2 \& 3}$ Professor, Department of Horticulture, Bangabandhu Sheikh Mujibur Rahman Agricultural University (BSMRAU), ${ }^{4}$ Professor, Department of Crop Botany, BSMRAU, ${ }^{5}$ Professor, Department of Soil Science, BSMRAU, Salna, Gazipur, Bangladesh. 
garden and also in landscaping. This flower is cultivated to a small scale in the periurban areas primarily for the supply to some city markets. Being a new crop, its fertilizer management is not known. As most of the soils of Bangladesh are deficient in major nutrients particularly $\mathrm{N}, \mathrm{P} \& \mathrm{~K}$, so judicial application of those nutrients can play a good role in successful production of hippeastrum.

Response of every crop in Bangladesh to nitrogen application is well documented since this element is deficient all over the country. Nitrogen is absorbed as $\mathrm{NH}_{4}{ }^{+}$ form by young plants whereas $\mathrm{NO}_{3}{ }^{-}$is the principal form utilized during the late growth stages. However, plants vary in their proportion of ammonium versus nitrate utilization (Bennett, 1993).

Proper management of nitrogen fertilization for hippeastrum bulb production is critical. Several studies showed that when bulbous plants are cultivated on the field, multiple applications of smaller amounts of nitrogen are the most efficient in reducing nitrate losses through leaching. Usually it is recommended that one third of the nitrogen is applied early in the growing season (1-8 weeks after planting) and the remaining two thirds of nitrogen will be applied in the late part of the growing season. This approach ensures nitrogen availability during the vegetative and reproductive phase of most bulbous plants (Slangen et al., 1989; Batal et al., 1994; Diaz-perez et al., 2003).

Phosphorus deficiency is considered as one of the major constraints to successful crop production. The ion absorption is determined by the $\mathrm{pH}$ of the soil. There is a notable effect of nitrogen on phosphorus uptake by plants.

Potassium is important in cell growth primary by through its effect on cell extension. With adequate potassium, cell walls are thicker and provide more tissue stability. This effect on cell growth normally improves resistance to lodging, pests and diseases. Potassium is required for production of high energy phosphate and is involved in starch as well as protein synthesis (Bennett, 1993).

Attention should therefore, be paid to the proportionate application of nitrogen, phosphorus and potassium. An excess amount of one nutrient element causes a relative or absolute deficiency of the other nutrients. The opposite is also true if there is a deficiency of some nutrient. In both cases the result is an "unbalanced diet" for the plants (Bergmann, 1992). In such a situation, balanced application of $\mathrm{N}, \mathrm{P} \& \mathrm{~K}$ which are deficient in most of our soils is imperative. Keeping this point in mind, the present study was undertaken to determine the response of hippeastrum to the application of different combinations of nitrogen, phosphorus and potassium levels.

\section{Materials and Method}

The experiment was carried out at the Horticultural Research Farm of Bangabandhu Sheikh Mujibur Rahman Agricultural University (BSMRAU), 
Salna, Gazipur during September 2008 to May 2009.The experimental site was located in the centre of the Madhupur Tract at about $24.09^{0}$ North latitude and $90.26^{0}$ East longitude having a mean elevation of $8.5 \mathrm{~m}$ on the sea level. The soil of the experimental field belongs to Salna series of Shallow Red Brown Terrace Soils. The soil is silty clay loam in texture and acidic in nature being characterized by poor fertility status and impeded internal drainage. Chemical characteristics of soil were $\mathrm{pH} 6.2$, organic matter content $0.95 \%$, total $\mathrm{N} 0.05 \%$, available $\mathrm{P} 26.0$ $\mathrm{mg} \mathrm{kg}$, copper $5.0 \mathrm{mg} \mathrm{kg}{ }^{-1}$, iron $53.0 \mathrm{mg} \mathrm{kg}{ }^{-1}$, manganese $46 \mathrm{mg} \mathrm{kg}^{-1}$, exchangeable $\mathrm{K} 0.3$ meq $100^{-1} \mathrm{~g}$ soil, available $\mathrm{S} 13.6 \mathrm{mg} \mathrm{kg}^{-1}$, and available $\mathrm{Zn}$ $1.86 \mathrm{mg} \mathrm{kg}^{-1}$ (Golder, 2000).

The experiment was laid out in a Randomized Complete Block Design with three replications. The total number of unit plots were 42 ( $14 \times 3)$, each measuring 1.0 $\mathrm{m} \times 1.0 \mathrm{~m}$ with $30 \mathrm{~cm}$ ridge around each plot and the blocks and plots were separated by $1.0 \mathrm{~m}$ and $0.75 \mathrm{~m}$, respectively. There were 14 treatment combinations comprising four levels of nitrogen viz. 0, 100, 200, and $300 \mathrm{kgha}^{-1}$; five levels of phosphorus viz. $0,200,300,400$ and $500 \mathrm{kgha}^{-1}$ and five levels of potassium viz. $0,100,200,300$ and $400 \mathrm{kgha}^{-1}$ with cowdung treatment at the rate of $10 \mathrm{tha}^{-1}$. The treatment combinations are shown in Table 1 under Result and Discussion section.

Nitrogen, phosphorus and potassium were applied in the form of urea, triple super phosphate (TSP) and muriate of potash (MOP), respectively. The entire quantity of cowdung and TSP and one-third each of urea and MOP were applied during plot preparation. The rest of urea and MOP were applied in two equal installments, 30 and 60 days after emergence. The variety of Hippeastrum used was Apple Blossom. Intercultural operations like irrigation, weeding, pest and disease control measures were taken as and when required. Data on different growth and flowering characteristics were collected from randomly selected 10 plants of each individual plots. The flower scape was cut when the buds were fully elongated. Harvesting was done early in the morning and the stalks were placed in water. The recorded data for different characters were analyzed statistically using MSTAT- C to find out the variation among the treatments. Treatment means were compared by Duncan's Multiple Range Test (DMRT) for interpretation of results (Gomez and Gomez, 1984).

\section{Results and Discussion}

The effect of different levels of nitrogen, phosphorus and potassium application on the growth and flowering of Hippeastrum cv. Apple Blossom are shown in different tables and figures.

\section{Days to first leaf emergence}

Days required for the first leaf emergence of hippeastrum varied significantly with different levels of N, P \& K application (Table 1). It appears that the earliest leaf 
emergence (15.3 days) commenced with the treatment $\mathrm{T}_{4}\left(\mathrm{~N}_{300} \mathrm{P}_{400} \mathrm{~K}_{300}\right)$ and $\mathrm{T}_{13}$ (cowdung 10 tha $\left.^{-1}\right)$ and are statistically similar with $\mathrm{T}_{3}\left(\mathrm{~N}_{200} \mathrm{P}_{400} \mathrm{~K}_{300}\right)$ while 36.0 days were required for treatment $\mathrm{T}_{9}\left(\mathrm{~N}_{200} \mathrm{P}_{400} \mathrm{~K}_{0}\right)$. Thus, higher dose of $\mathrm{N}, \mathrm{P} \& \mathrm{~K}$ combination and cowdung alone were most suitable for the first leaf emergence of hippeastrum bulb, but in absence of $\mathrm{K}$ and other combination of $\mathrm{N}$ and $\mathrm{P}$ it took longer time for the first leaf emergence.

\section{Leaves per plant}

Active leaf number was counted and highly significant variation was found due to different levels of N, P \& K treatment (Table 1). Leaf number varied from 5.40 to 8.60 per plant. The highest number of leaves (8.60) was recorded with the treatment $\mathrm{T}_{3}\left(\mathrm{~N}_{200} \mathrm{P}_{400} \mathrm{~K}_{300}\right)$ which was statistically similar with $\mathrm{T}_{11}\left(\mathrm{~N}_{200} \mathrm{P}_{400} \mathrm{~K}_{200}\right)$, $\mathrm{T}_{12}\left(\mathrm{~N}_{200} \mathrm{P}_{400} \mathrm{~K}_{400}\right), \mathrm{T}_{5}\left(\mathrm{~N}_{200} \mathrm{P}_{0} \mathrm{~K}_{300}\right)$ and $\mathrm{T}_{10}\left(\mathrm{~N}_{200} \mathrm{P}_{400} \mathrm{~K}_{100}\right)$. The lowest number of leaves per plant was noted with the control $\mathrm{T}_{14}\left(\mathrm{~N}_{0} \mathrm{P}_{0} \mathrm{~K}_{0}\right)$. Similar results were also reported by Dash et al. (2003) and Jaggi (2005) in onion. Shah et al. (1984) observed that higher doses of $\mathrm{N}, \mathrm{P} \& \mathrm{~K}$ encouraged producing higher number of leaves per plant in gladiolus.

\section{Plant height}

Plant height of hippeastrum was measured after flowering. It was observed that plant height was influenced significantly by different levels of $\mathrm{N}, \mathrm{P} \& \mathrm{~K}$ application (Table 1). The tallest plant $(63.8 \mathrm{~cm})$ was recorded in $\mathrm{T}_{4}\left(\mathrm{~N}_{300} \mathrm{P}_{400} \mathrm{~K}_{300}\right)$ and the shortest plant $(48.1 \mathrm{~cm})$ was found in control $\left(\mathrm{T}_{14}\right)$. The maximum vegetative growth was recorded with the application of higher levels of nitrogen. Shah et al. (1984) also found in gladiolus that increasing $N$ rates influenced the plant growth. Maximum vegetative growth in tuberose with the highest dose of $300 \mathrm{~kg} \mathrm{Nha}^{-1}$ was recorded by Yadav et al. (1985).

\section{Leaf breadth}

Leaf breadth of hippeastrum varied from $4.13 \mathrm{~cm}$ to $5.40 \mathrm{~cm}$ over the treatments (Table 1). The broadest leaf $(5.40 \mathrm{~cm})$ was recorded with $\mathrm{T}_{3}\left(\mathrm{~N}_{200} \mathrm{P}_{400} \mathrm{~K}_{300}\right)$ which was followed by and statistically similar with $\mathrm{T}_{10}\left(\mathrm{~N}_{200} \mathrm{P}_{400} \mathrm{~K}_{100}\right), \mathrm{T}_{11}\left(\mathrm{~N}_{200} \mathrm{P}_{400} \mathrm{~K}_{200}\right)$, $\mathrm{T}_{7}\left(\mathrm{~N}_{200} \mathrm{P}_{300} \mathrm{~K}_{300}\right), \mathrm{T}_{13}$ (cowdung @ 10 tha $\left.^{-1}\right), \mathrm{T}_{2}\left(\mathrm{~N}_{100} \mathrm{P}_{400} \mathrm{~K}_{300}\right)$ and $\mathrm{T}_{6}$ $\left(\mathrm{N}_{200} \mathrm{P}_{200} \mathrm{~K}_{300}\right)$. The narrowest leaf $(4.13 \mathrm{~cm})$ was produced from the control treatment $\left(\mathrm{N}_{0} \mathrm{P}_{0} \mathrm{~K}_{0}\right)$ produced. This result is in agreement with that of Prodhan et al. (2004) reporting that combined application of $\mathrm{N}$ at $400 \mathrm{kgha}^{-1}$ and $\mathrm{K}$ at 300 $\mathrm{kgha}^{-1}$ showed the highest values for leaf area. Low levels of nitrogen and phosphorus reduced the growth and affected flowering in tulip, as reported by Cheal and Winsor (1986). 


\section{Plantlets bulb ${ }^{-1}$}

Plantlets per bulb of hippeastrum were counted at the time of bulb lifting from the plot. Highly significant variation occurred in plantlets per bulb due to different $\mathrm{N}$, $\mathrm{P} \& \mathrm{~K}$ treatments (Table 1). The maximum plantlets per bulb (3.07) was obtained from the treatment $\mathrm{T}_{3}\left(\mathrm{~N}_{200} \mathrm{P}_{400} \mathrm{~K}_{300}\right)$ followed by $\mathrm{T}_{12}\left(\mathrm{~N}_{200} \mathrm{P}_{400} \mathrm{~K}_{400}\right), \mathrm{T}_{13}$ (cowdung @ 10 tha $^{-1}$ ) and $\mathrm{T}_{10}\left(\mathrm{~N}_{200} \mathrm{P}_{400} \mathrm{~K}_{100}\right)$. The $\mathrm{T}_{14}$ (control) treatment produced the minimum (1.60) plantlets per bulb; it was statistically similar to $\mathrm{T}_{1}\left(\mathrm{~N}_{0} \mathrm{P}_{400} \mathrm{~K}_{300}\right)$, $\mathrm{T}_{2}\left(\mathrm{~N}_{100} \mathrm{P}_{400} \mathrm{~K}_{300}\right)$ and $\mathrm{T}_{11}\left(\mathrm{~N}_{200} \mathrm{P}_{400} \mathrm{~K}_{200}\right)$. Similar result was also reported by Jana and Bose (1980) in hippeastrum where they obtained the maximum yield of bulbs, bulb-lets and flowers with a combined application of $200 \mathrm{~kg} \mathrm{~N}, 400 \mathrm{~kg}$ P and 200 $\mathrm{kg} \mathrm{K}$ per hectare.

Table 1. Growth characteristics of hippeastrum under different levels of N,P \& $\mathrm{K}$ application

\begin{tabular}{|c|c|c|c|c|c|c|c|c|}
\hline \multirow{2}{*}{$\begin{array}{l}\text { Treat- } \\
\text { ment }\end{array}$} & \multicolumn{3}{|c|}{$\begin{array}{l}\text { Treatment combination } \\
\qquad\left(\mathrm{kg} \mathrm{ha}^{-1}\right)\end{array}$} & \multirow{2}{*}{$\begin{array}{c}\text { Days to } \\
\text { first leaf } \\
\text { emergence }\end{array}$} & \multirow{2}{*}{$\begin{array}{c}\text { Leaves } \\
\text { plant }^{-1} \\
\text { (no.) }\end{array}$} & \multirow{2}{*}{$\begin{array}{c}\text { Plant } \\
\text { height } \\
(\mathrm{cm})\end{array}$} & \multirow{2}{*}{$\begin{array}{l}\text { Leaf } \\
\text { breadth } \\
(\mathrm{cm})\end{array}$} & \multirow{2}{*}{$\begin{array}{c}\text { Plantlets } \\
\text { bulb } \\
\text { (no.) }\end{array}$} \\
\hline & $\mathrm{N}$ & $\mathrm{P}$ & $\mathrm{K}$ & & & & & \\
\hline $\mathrm{T}_{1}$ & 0 & 400 & 300 & $27.0 \mathrm{~cd}$ & $6.00 \mathrm{bc}$ & $51.5 \mathrm{def}$ & $4.67 \mathrm{bc}$ & $1.67 \mathrm{c}$ \\
\hline $\mathrm{T}_{2}$ & 100 & 400 & 300 & $23.7 \mathrm{de}$ & $6.40 \mathrm{bc}$ & $50.3 \mathrm{ef}$ & $4.93 \mathrm{ab}$ & $1.73 \mathrm{c}$ \\
\hline $\mathrm{T}_{3}$ & 200 & 400 & 300 & $16.0 \mathrm{gh}$ & $8.60 \mathrm{a}$ & $55.5 \mathrm{bcd}$ & $5.40 \mathrm{a}$ & $3.07 \mathrm{a}$ \\
\hline $\mathrm{T}_{4}$ & 300 & 400 & 300 & $15.3 \mathrm{~h}$ & $6.80 \mathrm{bc}$ & $63.8 \mathrm{a}$ & $4.67 \mathrm{bc}$ & $2.00 \mathrm{bc}$ \\
\hline $\mathrm{T}_{5}$ & 200 & 0 & 300 & $29.0 \mathrm{bc}$ & $7.40 \mathrm{ab}$ & $55.9 \mathrm{bcd}$ & $4.80 \mathrm{ab}$ & $2.13 \mathrm{bc}$ \\
\hline $\mathrm{T}_{6}$ & 200 & 200 & 300 & $31.7 \mathrm{~b}$ & $6.47 \mathrm{bc}$ & $54.8 \mathrm{~b}-\mathrm{e}$ & $4.93 \mathrm{ab}$ & $1.80 \mathrm{bc}$ \\
\hline $\mathrm{T}_{7}$ & 200 & 300 & 300 & $23.3 \mathrm{e}$ & $5.87 \mathrm{bc}$ & 53.7 cde & $5.00 \mathrm{ab}$ & $2.2 \mathrm{bc}$ \\
\hline $\mathrm{T}_{8}$ & 200 & 500 & 300 & $19.3 \mathrm{fg}$ & $6.40 \mathrm{bc}$ & $57.2 \mathrm{bc}$ & $4.53 \mathrm{bc}$ & $2.07 \mathrm{bc}$ \\
\hline $\mathrm{T}_{9}$ & 200 & 400 & 0 & $36.0 \mathrm{a}$ & $6.93 \mathrm{abc}$ & 53.4 cde & $4.60 \mathrm{bc}$ & $2.20 \mathrm{bc}$ \\
\hline $\mathrm{T}_{10}$ & 200 & 400 & 100 & $30.3 \mathrm{bc}$ & $7.00 \mathrm{abc}$ & $51.6 \mathrm{def}$ & $5.07 \mathrm{ab}$ & $2.33 \mathrm{abc}$ \\
\hline $\mathrm{T}_{11}$ & 200 & 400 & 200 & $22.3 \mathrm{ef}$ & $7.67 \mathrm{ab}$ & $55.3 \mathrm{~b}-\mathrm{e}$ & $5.00 \mathrm{ab}$ & $1.80 \mathrm{c}$ \\
\hline $\mathrm{T}_{12}$ & 200 & 400 & 400 & $20.3 \mathrm{ef}$ & $7.47 \mathrm{ab}$ & $59.5 \mathrm{ab}$ & $4.67 \mathrm{bc}$ & $2.60 \mathrm{ab}$ \\
\hline $\mathrm{T}_{13}$ & \multirow{2}{*}{\multicolumn{3}{|c|}{$\begin{array}{l}\text { Only cowdung } 10 \mathrm{t} / \mathrm{ha} \text {. } \\
\text { control }\end{array}$}} & $15.3 \mathrm{~h}$ & $6.53 \mathrm{bc}$ & $51.6 \mathrm{def}$ & $5.00 \mathrm{ab}$ & $2.40 \mathrm{abc}$ \\
\hline $\mathrm{T}_{14}$ & & & & $29.0 \mathrm{bc}$ & $5.40 \mathrm{c}$ & $48.1 \mathrm{f}$ & $4.13 \mathrm{c}$ & $1.60 \mathrm{c}$ \\
\hline \multicolumn{4}{|c|}{ Level of significance } & $* *$ & $* *$ & $* *$ & $*$ & $* *$ \\
\hline \multicolumn{4}{|l|}{$\mathrm{CV}(\%)$} & 5.71 & 9.58 & 3.28 & 6.81 & 13.54 \\
\hline
\end{tabular}

Means having same letter(s) and without letter(s) in a column are not significant by DMRT.

** indicates significant at $1 \%$ level, * indicates significant at $5 \%$ level.

\section{Days to flower scape emergence}

Days taken to flower scape emergence of hippeastrum was significantly affected by different levels of NPK fertilizers and cowdung alone (Table 2). The earliest 
flower scape emerged at 172.3 days after planting (DAP) in $\mathrm{T}_{3}\left(\mathrm{~N}_{200} \mathrm{P}_{400} \mathrm{~K}_{300}\right)$ and was statistically at par with $\mathrm{T}_{6}, \mathrm{~T}_{11}, \mathrm{~T}_{12}, \mathrm{~T}_{13}, \mathrm{~T}_{4}, \mathrm{~T}_{5}, \mathrm{~T}_{3}$ and $\mathrm{T}_{2}$ while late flower scape emergence at 194.3 DAP was found with control i.e. $\left(\mathrm{N}_{0} \mathrm{P}_{0} \mathrm{~K}_{0}\right)$ which was statistically similar with treatment $\mathrm{T}_{7}\left(\mathrm{~N}_{200} \mathrm{P}_{300} \mathrm{~K}_{300}\right), \mathrm{T}_{8}\left(\mathrm{~N}_{200} \mathrm{P}_{500} \mathrm{~K}_{300}\right)$ and $\mathrm{T}_{9}$ $\left(\mathrm{N}_{200} \mathrm{P}_{400} \mathrm{~K}_{0}\right)$. Jana (1995) from microscopical studies on hippeastrum reported that the application of fertilizer needs to be completed by the onset of flower initiation which happened to be 120 days after planting of bulbs.

\section{Days to flower bud appearance}

Time required to flower bud appearance of hippeastrum varied significantly with different N, P \& K treatments (Table 2). Early flower bud (185.3 DAP) was found in $\mathrm{T}_{3}\left(\mathrm{~N}_{200} \mathrm{P}_{400} \mathrm{~K}_{300}\right)$ followed by $\mathrm{T}_{12}\left(\mathrm{~N}_{200} \mathrm{P}_{400} \mathrm{~K} 400\right)$ and $\mathrm{T}_{6}\left(\mathrm{~N}_{200} \mathrm{P}_{200} \mathrm{~K}_{300}\right)$. The plant in control treatment $\left(\mathrm{N}_{0} \mathrm{P}_{0} \mathrm{~K}_{0}\right)$ took the maximum time (207.3 DAP) to produce flower bud in the experiment. This result is an agreement with the findings of Bhattacharjee (1981) who found that application of $200 \mathrm{~kg}$ of $\mathrm{N}$ per hectare induced early flowering in gladiolus cv. 'Friendship' over lower doses whereas in the cultivar 'Vink's Glory' an addition of $500 \mathrm{~kg} \mathrm{Nha}^{-1}$ resulted in delayed flowering (Shah et al., 1984).

\section{Days to first flower open}

Non-significant difference was observed in case of first flower open of hippeastrum by different levels of N,P \& K fertilizers (Table 2). However, it can be revealed that days to the first flower open was the earliest (189.3 DAP) in $\mathrm{T}_{3}$ $\left(\mathrm{N}_{200} \mathrm{P}_{400} \mathrm{~K}_{300}\right)$ which was closely followed by $\mathrm{T}_{12}\left(\mathrm{~N}_{200} \mathrm{P}_{400} \mathrm{~K}_{400}\right)$ and $\mathrm{T}_{6}$ $\left(\mathrm{N}_{200} \mathrm{P}_{200} \mathrm{~K}_{300}\right)$. The control $\left(\mathrm{N}_{0} \mathrm{P}_{0} \mathrm{~K}_{0}\right)$ plant took the longest time (212.0 DAP) for the first flower open. The results are in agreement with the findings of Singh and Akhilesh (2003) who explained earlier flowering with $\mathrm{K}$ at the rate of 90 and 120 $\mathrm{kgha}^{-1}$.

\section{Flower scape per plant}

Flower scape per plant of hippeastrum was counted at the time of flower harvested. Significant variation was observed in the number of flower scape per plant due to different levels of N,P \& K fertilizers and cowdung alone (Table 2). The highest number of flower scape per plant (2.07) was observed in $\mathrm{T}_{3}\left(\mathrm{~N}_{200} \mathrm{P}_{400} \mathrm{~K}_{300}\right)$ which was closely followed by $\mathrm{T}_{13}$ (cowdung @ 10 tha $^{-1}$ ) and the lowest (1.00) was in the control $\left(\mathrm{N}_{0} \mathrm{P}_{0} \mathrm{~K}_{0}\right)$. In a sand culture experiment, Bose et al. (1980) reported that treatment with high level of nitrogen caused maximum plant growth and number of flower stalks and flowers. Treatment with phosphorus at the rate of $400 \mathrm{~kg}$ per hectare significantly increased the number of flower stalks and flowers as reported by Jana and Bose (1980). 
Table 2. Flowering characteristics of hippeastrum under different levels of nitrogen, phosphorus and potassium application

\begin{tabular}{|c|c|c|c|c|c|c|c|}
\hline \multirow[t]{2}{*}{ Treatment } & \multicolumn{3}{|c|}{$\begin{array}{c}\text { Treatment } \\
\text { combinations } \\
\left(\mathrm{kgha}^{-1}\right)\end{array}$} & \multirow{2}{*}{$\begin{array}{c}\text { Days to } \\
\text { flower scape } \\
\text { emergence }\end{array}$} & \multirow{2}{*}{$\begin{array}{c}\text { Days to } \\
\text { flower bud } \\
\text { appearance }\end{array}$} & \multirow{2}{*}{$\begin{array}{c}\text { Days to } \\
\text { first flower } \\
\text { open }\end{array}$} & \multirow{2}{*}{$\begin{array}{c}\text { Flower } \\
\text { scapeplant }^{-1} \\
\text { (no.) }\end{array}$} \\
\hline & $\mathrm{N}$ & $\mathrm{P}$ & $\mathrm{K}$ & & & & \\
\hline $\mathrm{T}_{1}$ & 0 & 400 & 300 & 184.0 a-d & $198.0 \mathrm{a}-\mathrm{d}$ & 204.0 & $1.07 \mathrm{e}$ \\
\hline $\mathrm{T}_{2}$ & 100 & 400 & 300 & $182.3 \mathrm{a}-\mathrm{d}$ & $196.0 \mathrm{a}-\mathrm{d}$ & 200.0 & $1.27 \mathrm{cde}$ \\
\hline $\mathrm{T}_{3}$ & 200 & 400 & 300 & $172.3 \mathrm{~d}$ & $185.3 \mathrm{~d}$ & 189.3 & $2.07 \mathrm{a}$ \\
\hline $\mathrm{T}_{4}$ & 300 & 400 & 300 & 180.7 a-d & $193.7 \mathrm{a}-\mathrm{d}$ & 198.7 & $1.93 \mathrm{abc}$ \\
\hline $\mathrm{T}_{5}$ & 200 & 0 & 300 & $181.3 \mathrm{a}-\mathrm{d}$ & $192.3 \mathrm{a}-\mathrm{d}$ & 196.7 & $1.07 \mathrm{e}$ \\
\hline $\mathrm{T}_{6}$ & 200 & 200 & 300 & $176.7 \mathrm{~cd}$ & $189.3 \mathrm{bcd}$ & 193.7 & $1.33 \mathrm{~b}-\mathrm{e}$ \\
\hline $\mathrm{T}_{7}$ & 200 & 300 & 300 & $192.7 \mathrm{ab}$ & $207.0 \mathrm{a}$ & 211.7 & $1.40 \mathrm{a}-\mathrm{e}$ \\
\hline $\mathrm{T}_{8}$ & 200 & 500 & 300 & $190.7 \mathrm{abc}$ & $205.0 \mathrm{ab}$ & 208.7 & $1.60 \mathrm{a}-\mathrm{e}$ \\
\hline $\mathrm{T}_{9}$ & 200 & 400 & 0 & $190.7 \mathrm{abc}$ & $203.3 \mathrm{abc}$ & 207.3 & $1.13 \mathrm{de}$ \\
\hline $\mathrm{T}_{10}$ & 200 & 400 & 100 & $188.7 \mathrm{abc}$ & $201.0 \mathrm{a}-\mathrm{d}$ & 207.3 & $1.60 \mathrm{a}-\mathrm{e}$ \\
\hline $\mathrm{T}_{11}$ & 200 & 400 & 200 & $179.7 \mathrm{a}-\mathrm{d}$ & $192.7 \mathrm{a}-\mathrm{d}$ & 198.0 & $1.20 \mathrm{de}$ \\
\hline $\mathrm{T}_{12}$ & 200 & 400 & 400 & $176.7 \mathrm{bcd}$ & $187.7 \mathrm{~cd}$ & 192.7 & $1.80 \mathrm{a}-\mathrm{d}$ \\
\hline $\mathrm{T}_{13}$ & $\begin{array}{l}\text { Only } \\
\text { t/ha. }\end{array}$ & cowdun & $\lg \quad 10$ & 180.0 a-d & $194.3 \mathrm{a}-\mathrm{d}$ & 196.0 & $2.00 \mathrm{ab}$ \\
\hline $\mathrm{T}_{14}$ & control & & & $194.3 \mathrm{a}$ & $207.3 \mathrm{a}$ & 212.0 & $1.00 \mathrm{e}$ \\
\hline \multicolumn{4}{|c|}{ Level of significance } & $*$ & $*$ & ns & $* *$ \\
\hline \multicolumn{4}{|l|}{$\overline{\mathrm{CV}(\%)}$} & 4.34 & 4.17 & 4.39 & 17.34 \\
\hline
\end{tabular}

Means having same letter(s) and without letter(s) in a column are not significant by DMRT. ** indicates significant at 1\% level, * indicates significant at 5\% level and 'ns' indicates non-significant.

\section{Flowers per scape}

Highly significant difference was observed in number of flowers per scape of hippeastrum due to different levels of N, P \& K fertilizers (Table 3). The maximum flowers per scape (4.20) was produced by the plant in $\mathrm{T}_{3}\left(\mathrm{~N}_{200} \mathrm{P}_{400} \mathrm{~K}_{300}\right)$ which was statistically similar with $\mathrm{T}_{13}$ (cowdung @ 10 tha $\left.^{-1}\right), \mathrm{T}_{8}\left(\mathrm{~N}_{200} \mathrm{P}_{500} \mathrm{~K}_{300}\right)$ and $\mathrm{T}_{11}$ $\left(\mathrm{N}_{200} \mathrm{P}_{400} \mathrm{~K}_{200}\right)$ whereas, the minimum (2.00) flowers per scape was noted with no $\mathrm{N}, \mathrm{P} \& \mathrm{~K}$ application $\left(\mathrm{N}_{0} \mathrm{P}_{0} \mathrm{~K}_{0}\right)$. The result is in agreement with the findings of Bhattacharjee et al. (1982) who stated that the number of flowers per plant increased with the application of NPK.

\section{Flower length}

A noticeable variation in the length of flower was recorded due to application of different levels of N, P \& K and cowdung application alone (Table 3). The longest 
flower $(14.0 \mathrm{~cm})$ was measured with $\mathrm{T}_{3}\left(\mathrm{~N}_{200} \mathrm{P}_{400} \mathrm{~K}_{300}\right)$ which was statistically similar with that of $\mathrm{T}_{13}$ (cowdung @10 tha $\left.{ }^{-1}\right), \mathrm{T}_{12}\left(\mathrm{~N}_{200} \mathrm{P}_{400} \mathrm{~K}_{400}\right)$ and $\mathrm{T}_{10}$ $\left(\mathrm{N}_{200} \mathrm{P}_{400} \mathrm{~K}_{100}\right)$. The shortest flower $(10.67 \mathrm{~cm})$ was produced with control $\left(\mathrm{N}_{0} \mathrm{P}_{0} \mathrm{~K}_{0}\right)$. Similar result was also reported by Jana and Bose (1980) who observed that the number of flowers and their size (diameter and length) were improved under high levels of nitrogen and phosphorus.

\section{Flower diameter}

Flower diameter was significantly influenced by different levels of N, P \& K supplement (Table 3). The biggest flower diameter of $13.83 \mathrm{~cm}$ was found in plants grown under $\mathrm{T}_{3}\left(\mathrm{~N}_{200} \mathrm{P}_{400} \mathrm{~K}_{300}\right)$ which was statistically similar with $\mathrm{T}_{13}$ (cowdung @ 10 tha $\left.^{-1}\right)$ and $\mathrm{T}_{12}\left(\mathrm{~N}_{200} \mathrm{P}_{400} \mathrm{~K}_{400}\right)$. The smallest flower diameter of $10.00 \mathrm{~cm}$ was recorded with the control treatment. This might be due to higher dose of nitrogen in combination with optimum dose of potassium and phosphorus leading to the better growth and development of plants resulted in high flower diameter in $\mathrm{T}_{3}$ treatment. This result is in agreement with the findings of Singh et al. (1965) and Bhattacharjee et al. (1982).

\section{Flower scape length}

Flower scape length of hippeastrum was measured at the time of harvesting. Flower scape length was influenced significantly by different levels of N P K fertilizers and cowdung alone (Table 3). The longest flower scape $(43.3 \mathrm{~cm})$ was recorded in $\mathrm{T}_{3}\left(\mathrm{~N}_{200} \mathrm{P}_{400} \mathrm{~K}_{300}\right)$ and the shortest flower scape $(26.0 \mathrm{~cm})$ was produced by control $\left(\mathrm{N}_{0} \mathrm{P}_{0} \mathrm{~K}_{0}\right)$ treatment. This might be due to fact that increasing $\mathrm{N}$ rates delayed flowering but influenced plant growth in terms the number of leavesplant ${ }^{-1}$, spike length and number of floretsspike ${ }^{-1}$. The results are in close agreement with the findings of Bhattacharjee (1981) who reported that $200 \mathrm{~kg}$ Nha $^{-1}$ increased flower spike length of tuberose. Similar results were also reported by Bankar and Mukhopadhyay (1980) in tuberose and Gowda et al. (1988) in gladiolus.

\section{Flower scape diameter}

Different levels of N, P \& K fertilizers exhibited significant variation on flower scape diameter of hippeastrum (Table 3). The maximum value for flower scape diameter $(29.4 \mathrm{~cm})$ was obtained with $\mathrm{T}_{3}\left(\mathrm{~N}_{200} \mathrm{P}_{400} \mathrm{~K}_{300}\right)$ and the minimum $(20.00$ $\mathrm{cm}$ ) was recorded with plants that grown without application of N, P \& K fertilizers. Jana and Bose (1980) observed that bulbs grown under $\mathrm{N}_{200} \mathrm{P}_{400}$ produced the widest flower stalks, whereas the narrowest flower stalk appeared in plants under $\mathrm{N}_{0} \mathrm{P}_{0}$ which is comparable with the present study. 
Table 3. Effect of N, P \& K on flower and flower scape characteristics of hippeastrum

\begin{tabular}{|c|c|c|c|c|c|c|c|c|}
\hline \multirow{2}{*}{$\begin{array}{c}\text { Treat- } \\
\text { ment }\end{array}$} & \multicolumn{3}{|c|}{$\begin{array}{c}\text { Treatment } \\
\text { combinations }\left(\mathrm{kgha}^{-1}\right)\end{array}$} & \multirow{2}{*}{$\begin{array}{c}\text { Flowers } \\
\text { Scape }^{-1} \\
\text { (no.) }\end{array}$} & \multirow{2}{*}{$\begin{array}{l}\text { Flower } \\
\text { length } \\
(\mathrm{cm})\end{array}$} & \multirow{2}{*}{$\begin{array}{l}\text { Flower } \\
\text { diameter } \\
\quad(\mathrm{cm})\end{array}$} & \multirow{2}{*}{$\begin{array}{c}\text { Flower } \\
\text { scape } \\
\text { length } \\
(\mathrm{cm})\end{array}$} & \multirow{2}{*}{$\begin{array}{c}\text { Flower } \\
\text { scape } \\
\text { diameter } \\
(\mathrm{mm})\end{array}$} \\
\hline & $\mathrm{N}$ & $\mathrm{P}$ & $\mathrm{K}$ & & & & & \\
\hline $\mathrm{T}_{1}$ & 0 & 400 & 300 & $2.13 \mathrm{~d}$ & $11.00 \mathrm{gh}$ & $10.17 \mathrm{hi}$ & $32.00 \mathrm{~b}$ & $23.57 \mathrm{~b}$ \\
\hline $\mathrm{T}_{2}$ & 100 & 400 & 300 & $2.73 \mathrm{bcd}$ & $11.17 \mathrm{fgh}$ & $11.50 \mathrm{~d}-\mathrm{g}$ & $26.00 \mathrm{~b}$ & $23.85 \mathrm{~b}$ \\
\hline $\mathrm{T}_{3}$ & 200 & 400 & 300 & $4.20 \mathrm{a}$ & $14.00 \mathrm{a}$ & $13.83 \mathrm{a}$ & $43.33 \mathrm{a}$ & $29.37 \mathrm{a}$ \\
\hline $\mathrm{T}_{4}$ & 300 & 400 & 300 & $3.67 \mathrm{ab}$ & $12.67 \mathrm{bcd}$ & $12.17 \mathrm{c}-\mathrm{f}$ & $26.00 \mathrm{~b}$ & $22.29 \mathrm{bc}$ \\
\hline $\mathrm{T}_{5}$ & 200 & 0 & 300 & $2.67 \mathrm{bcd}$ & $11.50 \mathrm{e}-\mathrm{h}$ & $10.83 \mathrm{ghi}$ & $29.67 \mathrm{~b}$ & $23.04 \mathrm{~b}$ \\
\hline $\mathrm{T}_{6}$ & 200 & 200 & 300 & $3.53 \mathrm{ab}$ & $12.00 \mathrm{c}-\mathrm{g}$ & $11.33 \mathrm{e}-\mathrm{h}$ & $27.33 \mathrm{~b}$ & $21.82 \mathrm{bc}$ \\
\hline $\mathrm{T}_{7}$ & 200 & 300 & 300 & $3.20 \mathrm{abc}$ & $12.17 \mathrm{~b}-\mathrm{f}$ & $12.17 \mathrm{c}-\mathrm{f}$ & $31.00 \mathrm{~b}$ & $23.81 \mathrm{~b}$ \\
\hline $\mathrm{T}_{8}$ & 200 & 500 & 300 & $4.00 \mathrm{a}$ & $12.50 \mathrm{~b}-\mathrm{e}$ & $11.83 \mathrm{c}-\mathrm{g}$ & $31.00 \mathrm{~b}$ & $23.83 \mathrm{~b}$ \\
\hline $\mathrm{T}_{9}$ & 200 & 400 & 0 & $2.40 \mathrm{~cd}$ & $11.67 \mathrm{~d}-\mathrm{h}$ & $11.17 \mathrm{f}-\mathrm{i}$ & $33.00 \mathrm{~b}$ & $24.00 \mathrm{~b}$ \\
\hline $\mathrm{T}_{10}$ & 200 & 400 & 100 & $3.60 \mathrm{ab}$ & $13.00 \mathrm{abc}$ & $12.67 \mathrm{a}-\mathrm{d}$ & $33.00 \mathrm{~b}$ & $24.26 \mathrm{~b}$ \\
\hline $\mathrm{T}_{11}$ & 200 & 400 & 200 & $3.87 \mathrm{a}$ & $12.50 \mathrm{~b}-\mathrm{e}$ & $12.50 \mathrm{~b}-\mathrm{e}$ & $30.83 \mathrm{~b}$ & $24.12 \mathrm{~b}$ \\
\hline $\mathrm{T}_{12}$ & 200 & 400 & 400 & $3.67 \mathrm{ab}$ & $13.17 \mathrm{ab}$ & $12.83 \mathrm{abc}$ & $29.17 \mathrm{~b}$ & $23.18 \mathrm{~b}$ \\
\hline $\mathrm{T}_{13}$ & $\begin{array}{l}\text { Only } \\
\text { t/ha. }\end{array}$ & cowdun & @ 10 & $4.07 \mathrm{a}$ & $13.83 \mathrm{a}$ & $13.50 \mathrm{ab}$ & $31.50 \mathrm{~b}$ & $23.60 \mathrm{~b}$ \\
\hline $\mathrm{T}_{14}$ & contro & & & $2.00 \mathrm{~d}$ & $10.67 \mathrm{~h}$ & $10.00 \mathrm{i}$ & $26.67 \mathrm{~b}$ & $20.00 \mathrm{c}$ \\
\hline Level & of sign & ance & & ** & $* *$ & $* *$ & $* *$ & $* *$ \\
\hline $\mathrm{CV}(\%$ & & & & 11.38 & 3.11 & 3.84 & 8.11 & 4.24 \\
\hline
\end{tabular}

Means having same letter(s) in a column are not significant by DMRT. ** indicates significant at $1 \%$ level.

\section{Flowering duration}

Highly significant variation was observed in freshness of flowers produced under different levels of N, P \& K application and cowdung alone (Fig. 1). It was found that flowers produced in $\mathrm{T}_{3}\left(\mathrm{~N}_{200} \mathrm{P}_{400} \mathrm{~K}_{300}\right)$ remained fresh for longer period (10.7 days) which was statistically varied with other treatments except the treatments $\mathrm{T}_{7}$ $\left(\mathrm{N}_{200} \mathrm{P}_{300} \mathrm{~K}_{300}\right)$ and $\mathrm{T}_{13}$ (Cowdung @ 10tha $\left.{ }^{-1}\right)$. The shelf life of flowers was the lowest (4.7 days) in control. The increased flowering duration could be attributed to the increased phosphorus levels in the experiment. Similar findings were also observed by Bhattacharjee et al. (1982) in hippeastrum where higher duration from full bloom to flower deterioration was observed in plants grown in increased dose $\left(400 \mathrm{kgha}^{-1}\right)$ of phosphorus. 


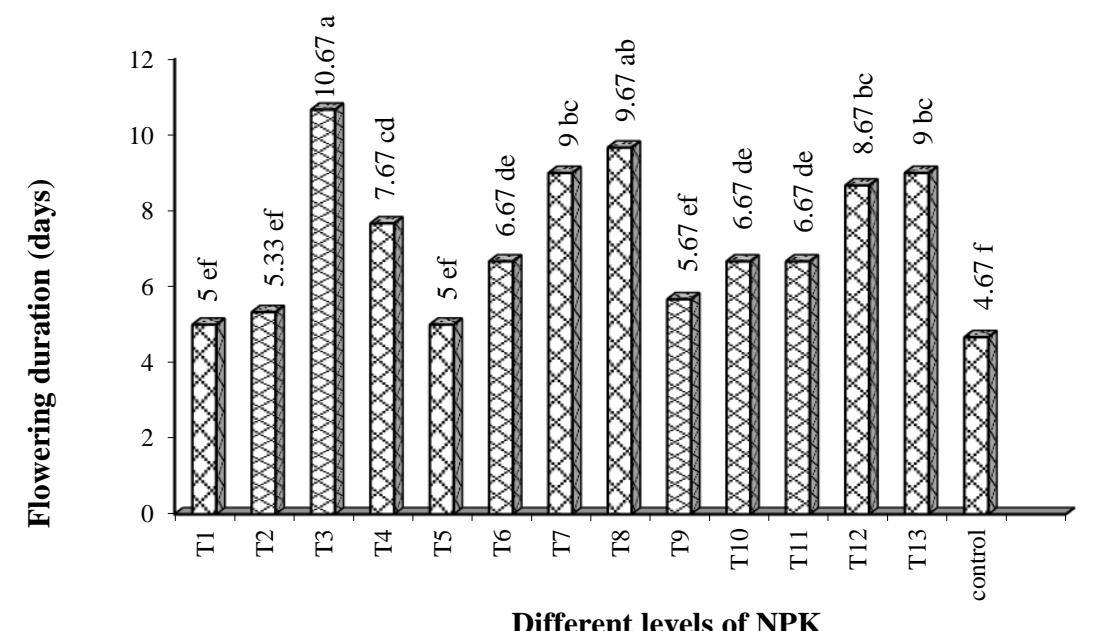

Fig. 1. Effect of different levels of NPK on flowering duration (days) of hippeastrum.

$\mathrm{T}_{1}=\mathrm{N}_{0} \mathrm{P}_{400} \mathrm{~K}_{300}, \mathrm{~T}_{2}=\mathrm{N}_{100} \mathrm{P}_{400} \mathrm{~K}_{300}, \mathrm{~T}_{3}=\mathrm{N}_{200} \mathrm{P}_{400} \mathrm{~K}_{300}, \mathrm{~T}_{4}=\mathrm{N}_{300} \mathrm{P}_{400} \mathrm{~K}_{300}, \mathrm{~T}_{5}=\mathrm{N}_{200} \mathrm{P}_{0} \mathrm{~K}_{300}, \mathrm{~T}_{6}$ $=\mathrm{N}_{200} \mathrm{P}_{200} \mathrm{~K}_{300}, \mathrm{~T}_{7}=\mathrm{N}_{200} \mathrm{P}_{300} \mathrm{~K}_{300}, \mathrm{~T}_{8}=\mathrm{N}_{200} \mathrm{P}_{500} \mathrm{~K}_{300}, \mathrm{~T}_{9}=\mathrm{N}_{200} \mathrm{P}_{400} \mathrm{~K}_{0}, \mathrm{~T}_{10}=\mathrm{N}_{200} \mathrm{P}_{400} \mathrm{~K}_{100}, \mathrm{~T}_{11}$ $=\mathrm{N}_{200} \mathrm{P}_{400} \mathrm{~K}_{200}, \mathrm{~T}_{12}=\mathrm{N}_{200} \mathrm{P}_{400} \mathrm{~K}_{400}, \mathrm{~T}_{13}=$ Cowdung @ 10t/ha. and $\mathrm{T}_{14}=$ Control.

\section{Conclusion}

Combined application of N, P \& K significantly influenced the growth and flowering of hippeastrum. Application at the rate of $200 \mathrm{~kg} \mathrm{~N}, 400 \mathrm{~kg}$ P and 300 $\mathrm{kg} \mathrm{K}$ per hectare performed the best in terms of growth and flower production of hippeastrum. Thus this rate can be recommended for the healthy growth and high quality flower production of hippeastrum in Salna Series of Shallow Red Brown Terrace Soils of Madhupur Tract.

\section{References}

Bankar, G. J. and Mukhopadhyay, A.1980. Varietal trial on tuberose (Polianthes tuberosa L.). South Indian Hort. 28(4): 150-151.

Batal, K. M., K. Bondari, D. M. Granberry, and B. G. Mullinix, 1994. Effects of source, rate, and frequency of $\mathrm{N}$ application on yield, marketable grades and rot incidence of sweet onion (Allium cepa L. cv. Granex-33). J. Hort. Sci. 69: 1043-1051.

Bennett, W.F., 1993. Plant nutrient utilization and diagnostic plant symptoms. In: W.F. Bennett (Ed). Nutrient deficiencies and toxicities in crop plants. APS Press, St Paul, Minnesota. Pp. 205-215.

Bhattacharjee, S. K. 1981. Influence of nitrogen, phosphorus and potash fertilization on flowering and corm production of gladiolus. Singapore J. Primary Ind. 9(1): 23-27.

Bhattacharjee, S. K., L. P. Yadev and T. Mukhopadhyay. 1982. Effect of nitrogen, phosphorus and potash fertilization on hippeastrum. Indian Agric. 26: 193-197. 
Bhattacharjee, S. K., R. Mallik, L. P. Yadav and T. Mukherjee. 1981. Response of Polianthes tuberosa Linn. to nitrogen, phosphorus and potash fertilization. Bull, Botan. Soc. Bengal. 35: 75-80.

Bose,T.K., B. K. Jana, and T.P. Mukhopadhyay. 1980. Effect of growth regulators on growth and flowering of Hippeastrum hybridum. Scientia Horticulturae. 12: 195-200.

Cheal, W.F. and G.W. Winsor. 1986. The effects of nitrogen, phosphorus, potassium and magnesium on the growth of tulips during the second season of treatment on the chemical composition of the bulbs. Ann. Appl. Biol. 57: 287-299.

Dash, S. K., D. P. Ray and L. Tripathy. 2003. Effect of nitrogen and potassium nutrition on growth and yield of multiplier onion (Allium cepa var. aggregatum L.) Indian J. Agric. 50 (3): 167-168.

Diaz-perez, P. J., A. C. Purvis, and J. T. Paulk, 2003. Bolting, yield, and bulb decay of sweet onion as affected by nitrogen fertilization. J. Ame. Soc. Hort. Sci. 128: 144-149.

Golder, P.C. 2000. Studies on growth, yield and quality of banana as affected by growth regulators. Ph.D. dissertation.Submitted to the Department of Horticulture, BSMRAU, Salna, Gazipur. P. 183.

Gomez, K.A. and A.A. Gomez. 1984. Statistical Procedures for Agricultural Research (2 $2^{\text {nd }}$ edition). Int. Rice Res. Inst. John Wiley and Sons publication, New York. Pp. 28-192.

Gowda, J.V.N., R. Jayanthi, and B. Raju. 1988. Studies on the effect on nitrogen and phosphorus on flowering in gladiolus cv. Devonair., Current Research, University of Agricultural Sciences, Bangalore. 17(6): 80-81.

Jaggi, R.C. 2005. Sulphur levels and sources affecting yield and yield attributes in onion (Allium cepa). Indian J. Agril. Sci. 75(3): 154-156.

Jana, B. K. and T. K. Bose. 1980. Effect of fertilizers on growth and flowering of hippeastrum. Indian Agric., 24: 23-30.

Jana, B.K. 1995. Cultural requirements of Hippeastrum. In: Advances in Horticulture. Vol. 12 Ornamental plants (eds.), Chadha, K.L. and S.K. Bhattacharjee, Malhotra publishing house, New Delhi, India.

Pradhan, A., J. N. Das, H. N. Misra and P. C. Lenka. 2004. Effect of N and K on growth and yield of gladiolus. Orissa J. Hort. 32(2): 74-77.

Shah, A. S. D. Lel and J. N. Seth, 1984. Effect of different levels of nitrogen and phosphorus on growth, flowering and corm yield of gladiolus, cv. Vink's Glory. Prog. Hort. 16(3-4): 305-307.

Singh, A. K. and S. Akhilesh. 2003. Seed production of onion as influenced by potassium and its method of application. Indian J. of Horticulture. 60(3): 287-289.

Slangen, J. H. G., G. J. Krook, C. H. M. Hendriks, and N. A. A. Hof. 1989. Nitrogen dressing and nutrient absorption of lilies (Asiatic hybrids) on sandy soils. Neth. J. Agric. Sci. 37: 269 -272.

Yadev, L. P., T, K. Bose, and R, G. Maity, 1985. Response of tuberose (Polianthes tuberosa L.) to nitrogen and phosphorus fertilization. Progressive Horticulture. 17(2): 83-86.

Zandbergen, F.1980. Alfabetische Lijst van de ir Nederland in cultuur zijnde Amaryllis (Hippeastrum) cultivars. Koninklijke Algemeene Vereeniging voor Bloembol lencultuur, Hillegom, The Netherlands, P. 81 